
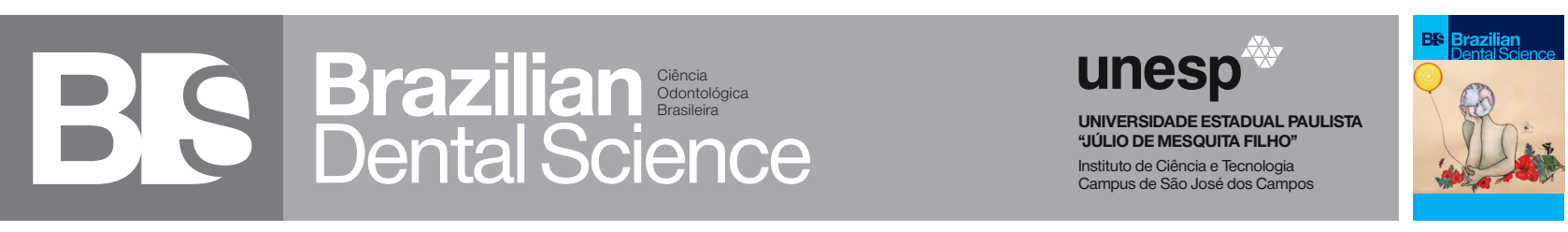

\title{
Multidisciplinary approach for anatomical correction and diastema closure with laminates veneers: a clinical report
}

Abordagem multidisciplinar para correção anatômica e fechamento de diastemas com facetas laminadas: relato de caso clínico

Alfredo Esteban LLERENA-ICOCHEA ${ }^{1}$, Marilia Mattar de Amoêdo Campos VELO ${ }^{1}$, Ana Flávia Sanches BORGES ${ }^{1}$, Rafael Francisco Lia MONDELLI ${ }^{1}$, Adilson Y FURUSE ${ }^{1}$

1 - Department of Operative Dentistry - Endodontics and Dental Materials - Bauru School of Dentistry - University of São Paulo - Bauru São Paulo - Brazil.

\section{ABSTRACT}

Objective: multidisciplinary treatment has become increasingly common in dental offices and this treatment strategy is based on the achievement of a healthy, harmonious, and pleasant smile. In addition, the development of new ceramic systems and the possibility of making indirect restorations with a low thickness, such as laminates veneers, allowed combining highly satisfactory aesthetic properties, preserving the dental structure through minimally Invasive technique. Case report: this paper describes a multidisciplinary approach involving periodontics and restorative dentistry for the successful, functional, and aesthetic treatment in an adult patient. The digital smile design was performed as a guide to plan the clinical case considering factors such as tooth inclination and position, golden proportion, tooth size and shape. Discussion: based on these concepts, the present work reports, through a clinical case, the restoration of aesthetics and function with ceramic laminates veneers in lithium disilicate, in the case of anatomical correction and diastema closure. Conclusion: overall, the multidisciplinary treatment plan demonstrated to have greater advantages both for the aesthetics and function of the patient, as well as for the work team. During the 24-month follow-up, this case presented great functional and aesthetics results.

\section{KEYWORDS}

Ceramic veneers; Aesthetic dentistry; Multidisciplinary treatment.

\section{RESUMO}

Introdução: o tratamento multidisciplinar tornou-se cada vez mais comum nos consultórios odontológicos, sendo uma estratégia baseada no tratamento da obtenção de um sorriso saudável, harmonioso e agradável. Além disso, o desenvolvimento de novos sistemas cerâmicos e a possibilidade de fazer restaurações indiretas com baixa espessura, como facetas laminadas, permitiram combinar propriedades estéticas altamente satisfatórias, preservando a estrutura dentária com o mínimo desgaste. Caso clínico: este artigo descreve uma abordagem multidisciplinar envolvendo Periodontia e Odontologia restauradora para um tratamento funcional e estético em um paciente adulto. O desenho digital do sorriso foi realizado como um guia para planejar o caso clínico, considerando fatores como inclinação e posição do dente, proporção áurea, tamanho e formato do dente. Discussão: com base nesses conceitos, o presente trabalho relata, através de um caso clínico, a restauração estética e funcional com laminados cerâmicos em dissilicato de lítio para correção anatômica e fechamento de diastemas. Conclusão: em geral, o plano de tratamento multidisciplinar demonstrou ter maiores vantagens tanto para a estética e função do paciente, quanto para a equipe de trabalho. Durante os 24 meses de acompanhamento, esse caso apresentou ótimos resultados funcionais e estéticos.

\section{PALAVRAS-CHAVE}

Laminados cerâmicos; Odontologia estética; Tratamento multidisciplinar. 


\section{INTRODUCTION}

$\mathrm{T}$ he aesthetic principles have a fundamental role in Restorative Dentistry. A systematic aesthetic analysis that progresses from facial, dentofacial, dentogingival to dental analysis is mandatory for a successful aesthetic outcome of the case [1]. Therefore, multidisciplinar treatment has become increasingly necessary and common in dental offices, particularly for the resolution of more complex clinical cases [2], aiming at an accurate diagnosis in order to achieve acceptable aesthetic results, such as satisfactory functional results [2-4].

Several authors report that the relative height, width, orientation, and the number of teeth, as well as the size and shape of the dental arches may contribute to proper tooth and arch interrelationships [1]. The goal is to have the maxillary anterior teeth restore optimal dentolabial relations in harmony with the overall facial appearance.

In complex cases, new methods and technological tools have boosted to be applied in the different branches of dentistry to assist in the diagnosis and planning. The digital smile design (DSD) is highlighted as a tool to guide the treatment planning process and has been used to seeks the digital interrelation between dentists of different specialties and the technicians of prosthesis, as well as to improve the communication with the patient [5]. Although digital techniques and dental materials evolution are capable of high success rates to achieve excellent aesthetic results, it is important that the tooth and gingival level be in accordance with the adjacent one. In this context, the combination of surgical-prosthetic treatments can offer more harmonious and predictable results in order to improve not only the proportion and dental anatomy, but also the morphology and gingival architecture, generating a more pleasant smile composition [6].

With the evolution of ceramic systems and the development of vitreous reinforced ceramics, such as lithium disilicate, ceramic restorations with low thickness (0.1 to 0.5 $\mathrm{mm}$ ) can be performed for morphological corrections. The greatest advantage of this type of restorations is the preservation of the dental structure, considering that a minimum preparation is required [7]. This type of indirect restoration is restricted to the enamel, has sedimented concepts with respect to the greater longitudinal durability, considering that this type of ceramic material used is etchable and its behavior regarding the different adhesive systems allow a reliable and lasting union [8].

The present clinical case report aims to describe the clinical protocols involved in the treatment with a multidisciplinary approach, combining the planning and treatment with a multidisciplinary approach for diastema closure with ceramic veneers.

\section{CASE REPORT}

A female patient sought treatment with the chief complaint of the proportion, color, shape and harmony of the smile. For the complete analysis of the case and a better planning, it was preceded with a photographic protocol (Figures 1 and 2). Clinical examination revealed the presence of large composite resin restorations that were unsatisfactory and had a color alteration in the teeth \#11,\#12 and \#22. In addition, there was a lack of harmony in the morphology of the anterior teeth and changes in the gingival level.

The different treatment plans were presented to the patient and a conservative, aesthetic and multidisciplinary approach was adopted, with periodontal regularization and the preparation of eight lithium disilicatebased laminates veneers to improve the smile harmony. It was also decided to carry out a digital smile design (DSD) protocol to present the case to the team and the patient, thus providing greater predictability of the definitive treatment (Figure 3). Digital pictures were obtained with a SLR Nikon D7100, Nikon Macro 85-mm lens and a Nikon R1C1 twin flash. The camera was adjusted in 
manual mode to f/16, 1/125 and ISO 200.

According to the DSD evaluation, there was a need for an increase in clinical crown length to ensure the desired harmony and proportionality. Next, 3-point probing was performed on all upper anterior teeth and, because values higher than $4 \mathrm{~mm}$ depth were observed (Figure 4), it was defined that only removal of the gingival tissue would be necessary for obtaining desired results.

Therefore, it was chosen to perform gingivoplasty with an external bevel incision (Figures 5 and 6), removing the gingival tissue in both height and thickness. After the finishing and smoothing of the incision lines, the relation between the cervical margins was again verified and the surgical area was operated with surgical cement. After 90 days of healing (Figure 7), the structures present in the biological space were already formed and it was possible to follow the restorative treatment.

Subsequently, to improve the color of the substrate, a bleaching was carried out. After prophylaxis and color register, a session with $35 \%$ hydrogen peroxide gel (Whiteness HP Maxx - FGM, Joinville, SC, BR) was performed with a hybrid LED / Laser light (Whitening Lase II - DMC, São Carlos, SP, BR), and 2 gel exchanges. After in-office bleaching, the home bleaching with a tray (White Class 7.5\% - FGM, Joinville, SC, BR) was performed for 21 days (Figures 8 and 9). Posteriorly, an addition silicone molding (Express XT - 3MESPE) was completed to make the study models. Based on the photographic analysis and the digital design, the diagnostic waxing was performed.

After color stabilization, different silicone guides (Zetaplus, Zhermack, Labordental, São Paulo, Brazil) were used to perform the mockup and both vertical and horizontal wear guides to have a better control in the height and thickness of the preparations. Afterward, the unsatisfactory composite resin restorations were removed from teeth \#11, \#12 and \#22. For this purpose, a fluorescent light (FGM; Joinville; São Carlos, Brazil) was used, thus exposing the resinous material of the healthy dental tissue (Figure 10).

After the mock-up was performed, a selfcuring resinous material (VOCO STRUCTUR 2) was used (Figure 11) and the definitive treatment was accepted by the patient. Then, dental preparations for laminates veneers were performed restricted to the enamel. For this purpose, wear orientation matrices were used to take care of the thickness and height of the preparations. A 5: 1 speed multiplier (NSK) was used for greater wear control (Figure 12). For the vestibular and cervical area, truncated conical diamond tips with rounded tip of normal granulation and fine granulation were used (KG Sorensen, São Paulo, Brazil). (KG Sorensen, São Paulo, Brazil) with the objective of creating minimum separation between the teeth to be prepared, in order to facilitate the demarcation of the margin at this level, obtaining a favorable insertion axis of the ceramic parts and facilitate the final printing for laboratory process.

Finally, to avoid any retentive area, all angles were rounded with the aid of abrasive discs (FGM, Joinville, SC, BR) and Abrasive Rubbers (Astropol, Ivoclar Vivadent, Schaan, Liechtenstein) were used to regularize and final polishing of the preparations were conducted.

For the molding procedure, a double viscosity polyvinyl siloxane material (Scan Putty and Scan Light - Yller, Pelotas, RS, BR) was used. Two retractor cords of different thicknesses \# 000 and \# 00 (Ultrapack, Ultradent; São Paulo, Brazil) were used. The first one remained in the gengival sulcus until the end of the procedure serving as a homeostasis agent and the second exerting the retraction needed.

Before the light silicone application, this last cord was removed. After the material polimerization, the first retraction cord was removed. After that, for a better comunication with the laboratory, the color selection was made with photograph help. Finally, 
provisional restorations with bisacrylic resin were fabricated. (Structur 2 SC, Voco, Cuxhaven, Germany) The molds were then sent to the prosthetics for the preparation of the eight lithium disilicate laminates veneers. (E.max Press Impulse V2, Ivoclar Vivadent, São Paulo, Brazil).

After the fabrication of the laminates, the cementation process began. The first step was the dry test of the prosthetic pieces, that is to say without any type of agent between the laminates and the preparations. This was done for the verification of insertion axis, adaptation, shape and alignment of all parts (Figure 13).

Next, a wet proof was performed using a glycerin-based test paste for final color selection of the final cement (AllCem Veneer - Try-in; FGM Products; Santa Catarina, Brazil). After this test, it was possible to observe that the Opaque White color cement would better mimic with the color of the substrate (Figure 14).

Then, prophylaxis was done with pumice stone and after placement of modified absolute isolation, the cementation process was carried out. For this, the prosthetics pieces were internally treated with 10\% hydrofluoric acid (Condac Porcelana 10\%, FGM Produtos, Santa Catarina, Brazil) for 20 seconds each. To avoid contact of the acidic agente with the vestibular surfasse, a PVS in heavy body was used. They were then washed and dried abundantly. Next, the silane agente (Prosil; FGM Products; Santa Catarina, Brazil) was placed in each laminate for 60 seconds for chemical reaction. Therefore, an adhesive layer (Ambar Universal, FGM Produtos, Santa Catarina, Brazil) was applied. After application, the adhesive was not lightactivated.

On the substrate, acid conditioning with 37\% phosphoric acid (Condac 37; FGM Produtos; Santa Catarina, Brazil) was applied for 30 seconds. Then, teeth were washed with copius water and air dried. After that, a thin layer of the same adhesive placed on the laminates veneers were applied. The cementing agent used was a light-activated resin cement (AllCem Veneer; FGM Products; Santa Catarina, Brazil), Opaque White color. The laminates were taken in position and before ligth activation all excess was carefully removed with the aid of a brush (Figure 15). After ensuring all excess cement was removed, the prosthetic pieces were photoactivated for 40 seconds on each side. Afterwards, the margins were checked for any cervical and proximal excesses. For this, it was used a number 12 scallpel blade as well as composite resin rubbers for finishing of the margins ass well. Intra oral final photos were performed after one week (Figures 16 and 17). After 24-month follow-up, this case presented great functional and aesthetics results.

\section{DISCUSSION}

The use of laminates veneers as minimally invasive restorations is not new in the literature [9]. Studies have shown that the survival rate of this type of restorations is more than $90 \%$ in up to 10 years of clinical follow-up; always and when the technique of preparation and cementation were well executed [10-12]. In the present case report, a multidisciplinary approach was able to be utilized due to a correct diagnosis and planning aided by extraoral and intraoral photographs, digital planning, diagnostic waxing and a mock up, thus providing a greater predictability of the minimally invasive treatments that were produced. The treatment plan for the increase of clinical crown length should always consider the need for associated prosthetic rehabilitation, since the aesthetic harmony at the level of the gingival margin and the contact with the future prosthetic restoration is considered one of the most important factors to reach a harmonious smile. Therefore, not only the basic periodontal procedures play an important role in the final aesthetic result, but also the mucogingival procedures as well.

Two patterns are acceptable with respect to the height of the gingival margin in 
aesthetic areas [13]: 1) the gingival margin of the upper central incisors (UCI) and canines (UC) should be at the same height, the margin of the lateral incisors (LI) positioned to the incisal of 1 to $2 \mathrm{~mm}$ (Class 1 ); and 2) the UCI, $\mathrm{LI}$ and UC at the same time (Class 2). It was identified that the patient already presented a Class 1 pattern (figure 2), such that there was no need to correct this gingival margin ratio. The dental width/height ratio may be easily evaluated by DSD approaches.

Correct case selection and indication are the main aspects of success with this type of procedure. Cases of diastema closure, alteration of tooth shape and contour, minor alignment corrections, and thickness and height gain may be resolved [14]. Thus, clinicians should also pay attention to the different contraindications, such as patients with severe bruxism, parafunctional activity and altered overbite and overjet [15].

In the present case, lithium disilicate was used as the material for the manufacture of laminates veneers. This material, vitreous and reinforced by particles, has good optical properties and excellent mechanical properties such as 400 $\mathrm{MPa}$ of flexural strength when injected [16]. In addition, the silica-based structure benefits from hydrofluoric acid conditioning to increase the internal surface area for mechanical retention and can also be silanized to increase the chemical interaction with the resin cement used in the cementation [17].

In the cementation process, after internal acid etching with hidrofluoridric acid and silanization, an universal adhesive was applied, without being further light-activated before the application of the resin cement. This approach is interesting to improve the adaptation of the veneer to the dental structure. It has been shown that this type of conduct would not influence negatively on the final shear bond strength to a vitreous ceramic [18]. In the cementation, a resin-based lightactivated veneer cement was used. According to the literature, various materials would be well indicated for cementing fine or ultrafine restorations, for example, fluid resin or heated composite resin. All of these maintain good color stability over time [19]. It should be noted however that, the type and thickness of the ceramic plays an important role in the properties of this veneer resin cements [20].

Within the resin cement materials, the contraindication for this type of restorations would be the dual cements, since it has been seen that over time they undergo an oxidation of the co-initiating amines that do not react after the polymerization, thus damaging the color stability [21], especially in fine aesthetic restorations in the anterior sector.

Overall, the multidisciplinary treatment plan demonstrates to have greater advantages both for the aesthetics and function of the patient, as well as for the work team. New non-invasive restorative ducts are increasingly used and to be properly executed, they need a thorough design to achieve the desired aesthetic results [22].

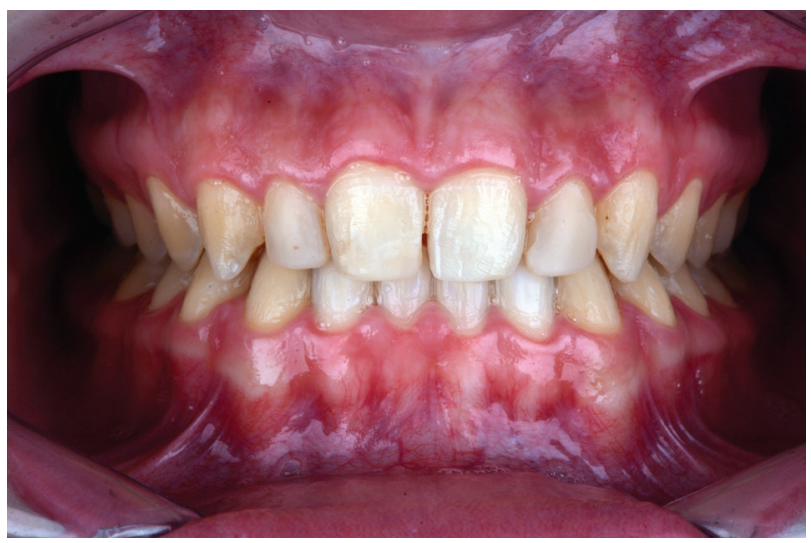

Figure 1 - Initial photography protocol (intra oral).

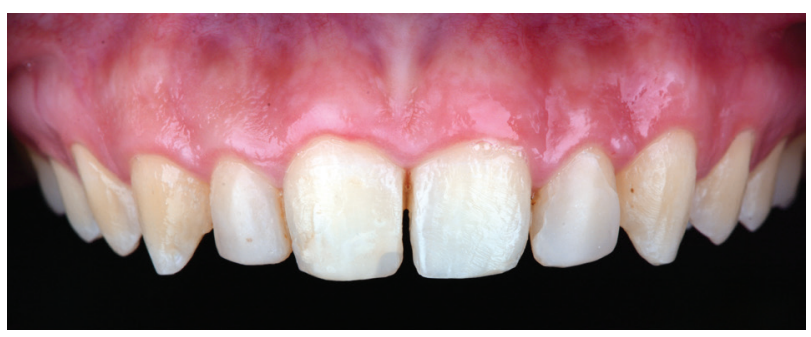

Figure 2 - Initial aspect of photographic protocol for digital smile design. 


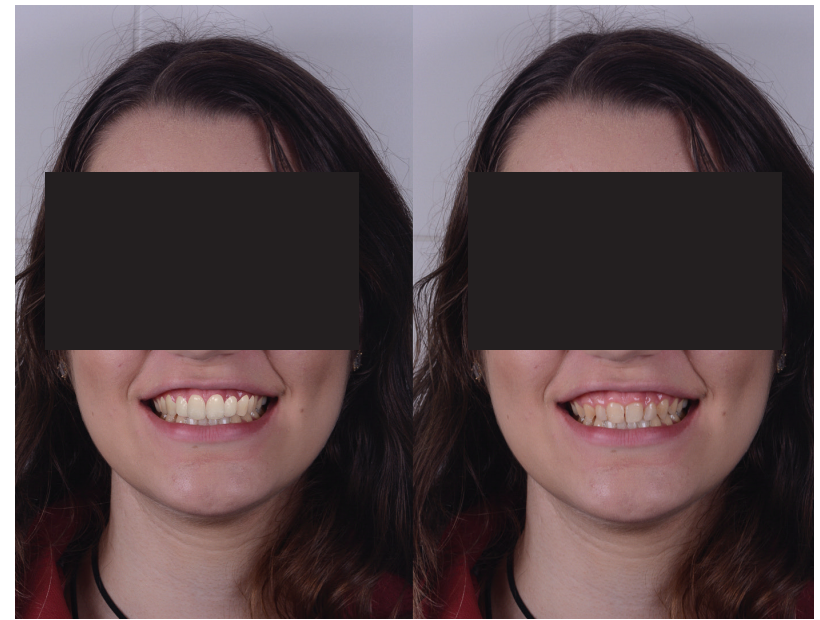

Figure 3 - Extra oral (frontal images) of the patient for digital smile protocol analysis.

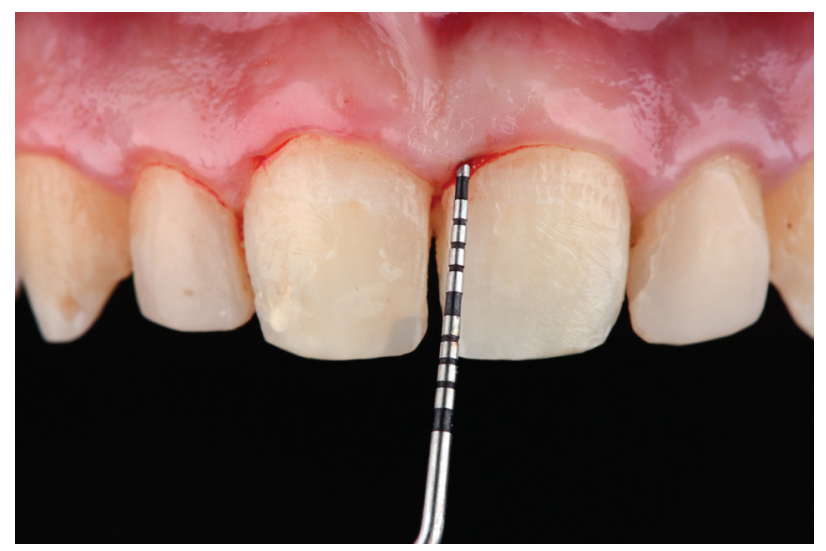

Figure 4 - Point probing analysis on the upper anterior teeth.

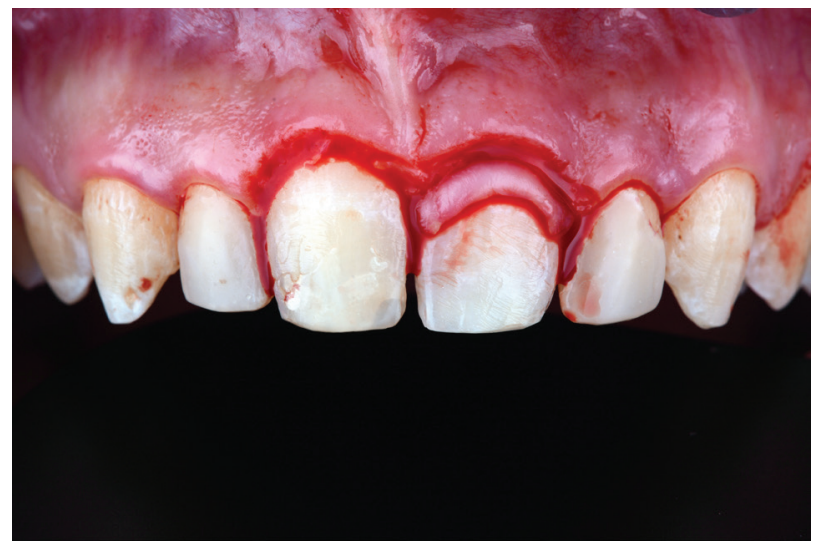

Figure 5 - Gingivoplasty procedure with an external bevel incision.

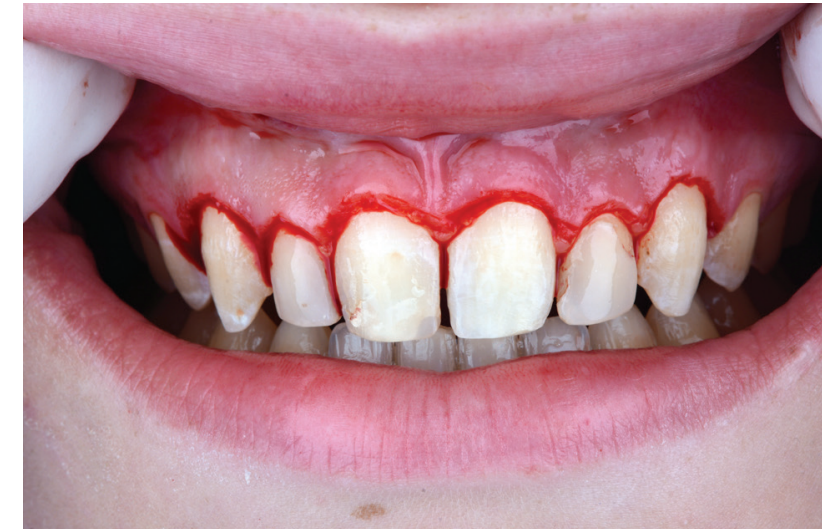

Figure 6 - Gingivoplasty procedure removing the gingival tissue in both height and thickness.

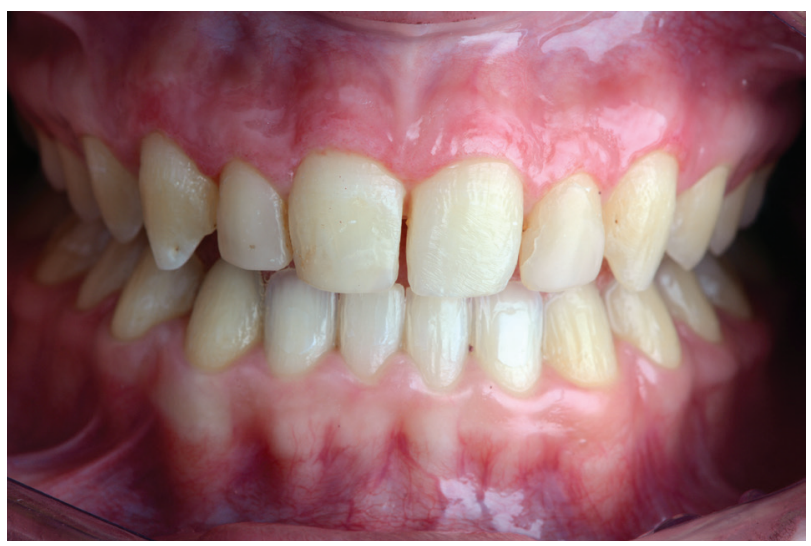

Figure 7 - Healing of the structures in the biological space after 90 days of surgical procedure.

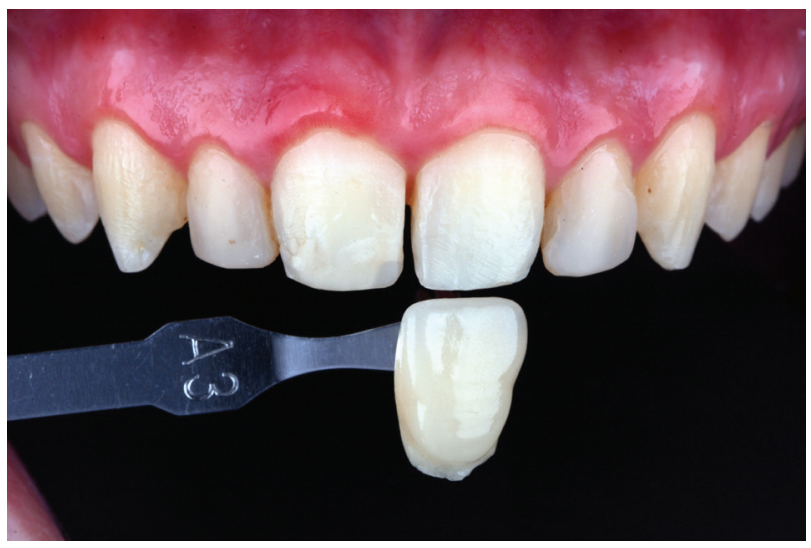

Figure 8 - Initial color of the teeth (shade A3). 


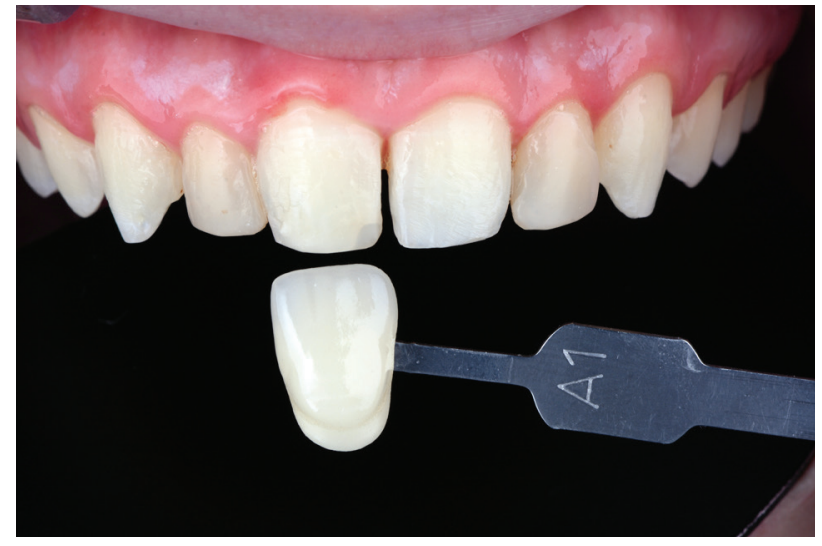

Figure 9 - After bleaching, the color was registered as shade A1.

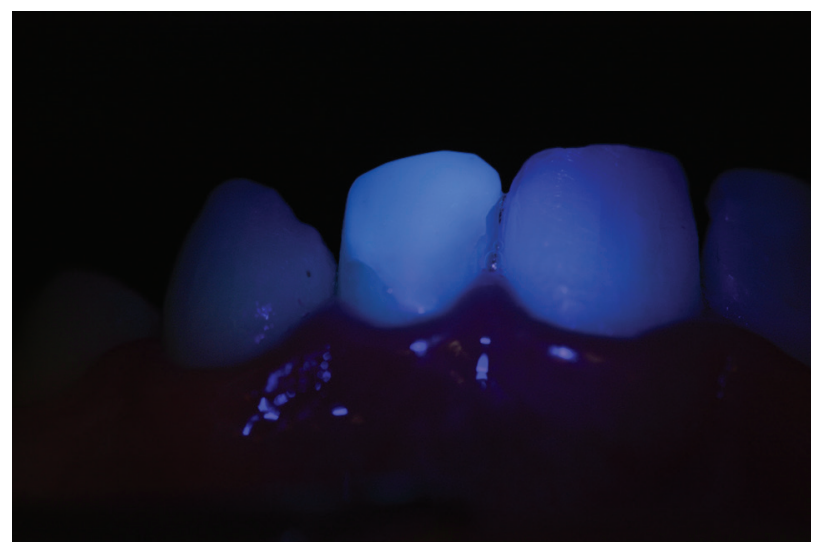

Figure 10 - The unsatisfactory composite resin restorations were removed from teeth using a fluorescent light.

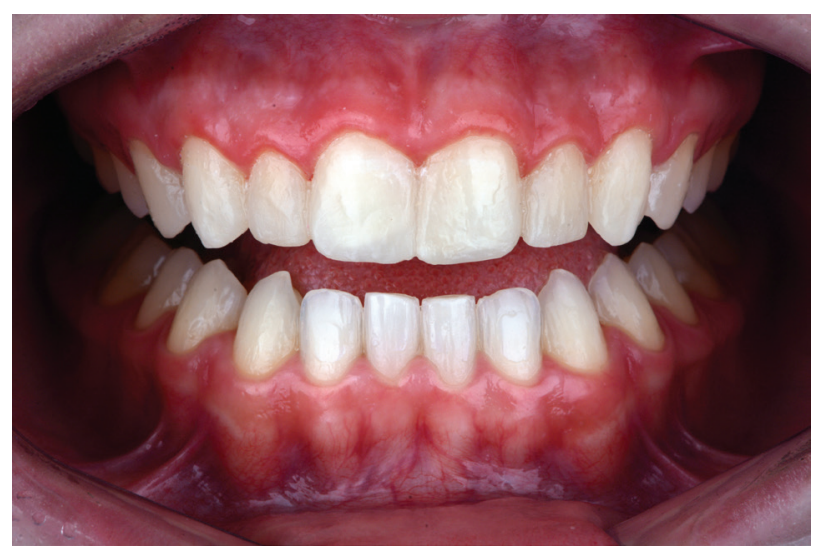

Figure 11 - Mock-up using a self-curing resinous material.

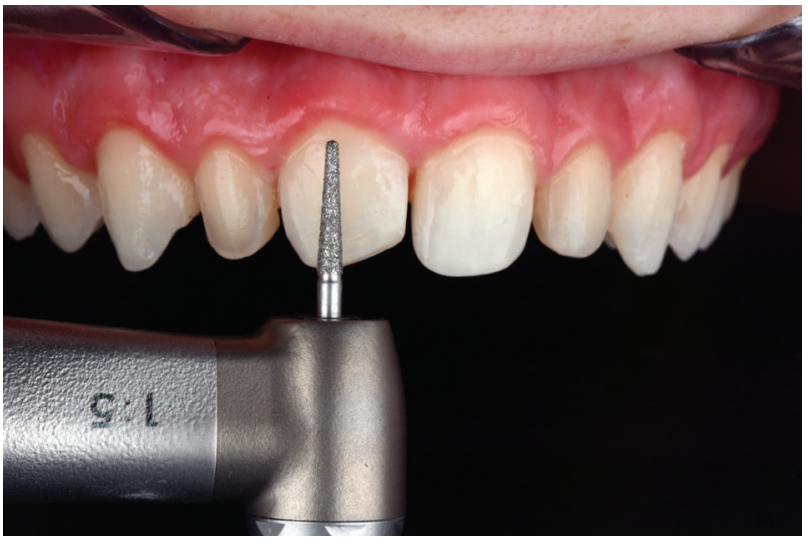

Figure 12 - Dental preparations for laminates veneers restricted to enamel.

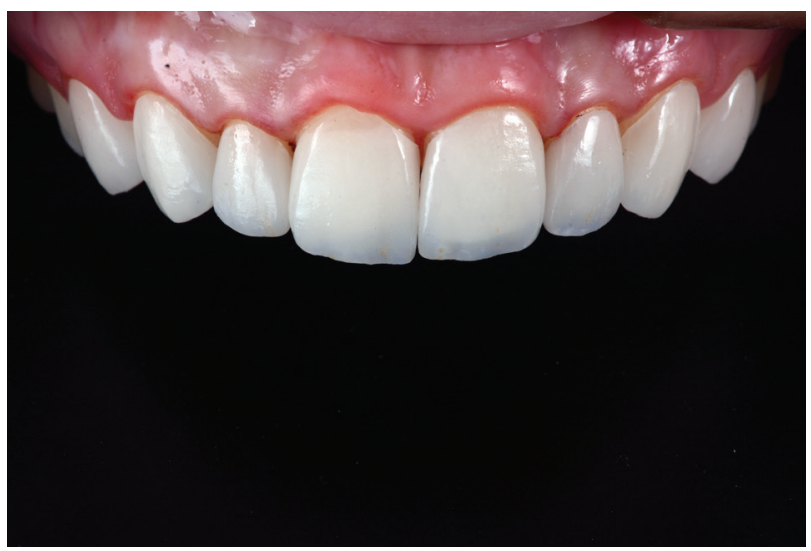

Figure 13 - Dry test of the laminated veneers.

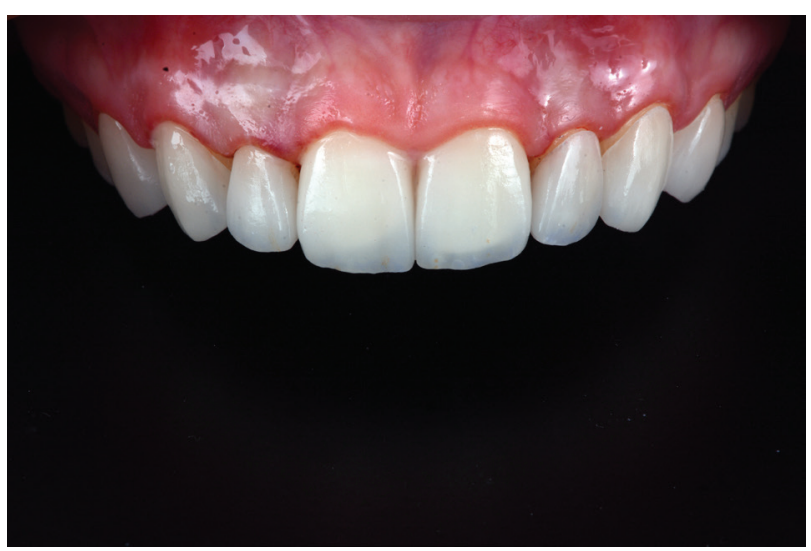

Figure 14 - Proof of the veneers using a glycerin-based test paste for final color selection of the final cement. 


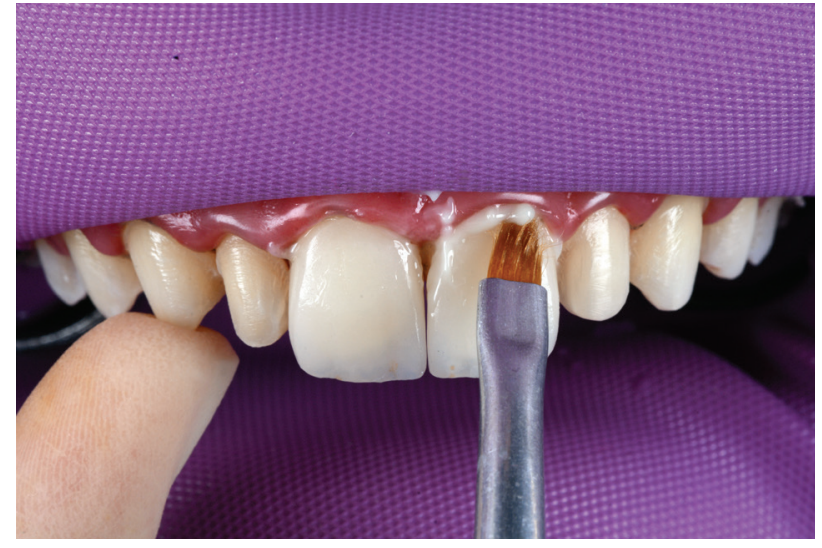

Figure 15 - Process before light-activation removing all excess with the aid of a brush and dental floss.

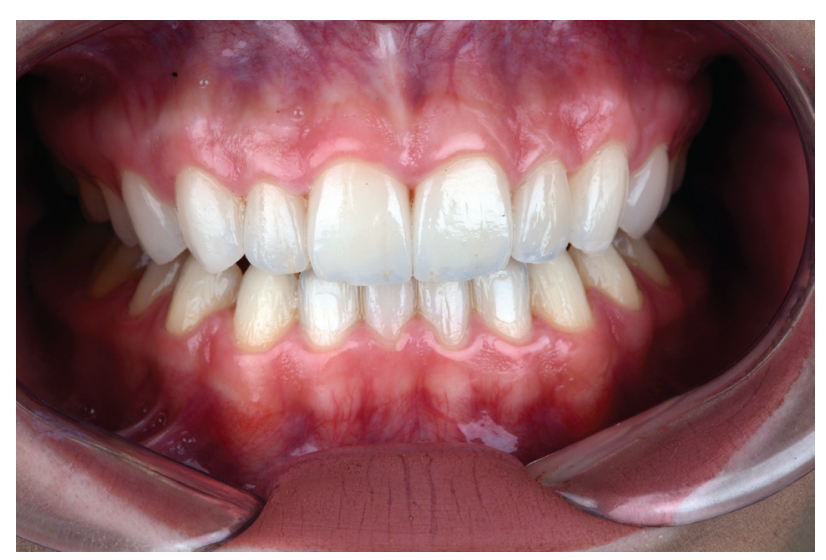

Figure 16 - Intra oral final photography.

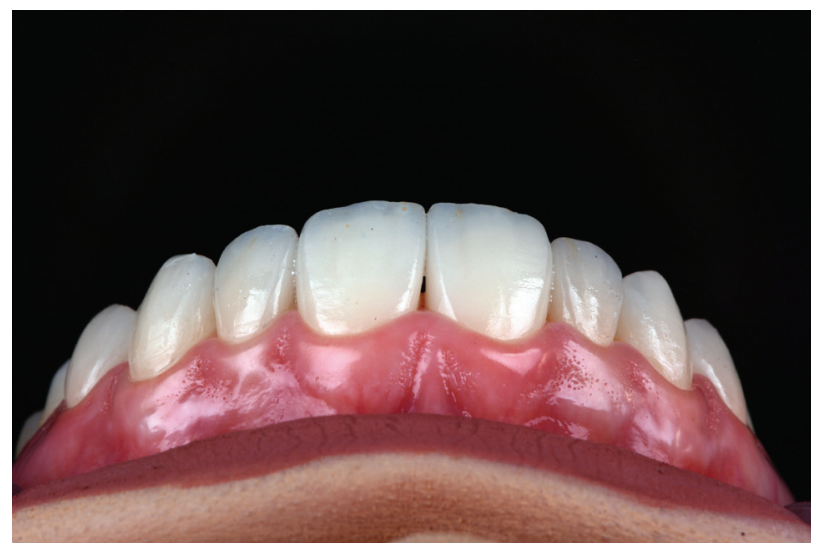

Figure 17 - Intra oral final photography after 1 week.

\section{CONCLUSIONS}

The present case report shows emphasizes that, to achieve aesthetic results, a multidisciplinary approach is necessary. The use of DSD guided the treatment planning process with ceramic veneers, a viable treatment option for anterior restorations. In a 24-month followup, this case presented great functional and aesthetics results.

\section{REFERENCES}

1. Oquendo A, Brea L, David S. Diastema: correction of excessive spaces in the esthetic zone. Dent Clin North Am. 2011;55(2):265-81.

2. Furuse AY,Franco EJ, Mondelli J. Esthetic and functional restoration for an anterior open occlusal relationship with multiple diastemata: a multidisciplinary approach. JProsthetDent.2008;99(2):91-4.

3. Nahas de Castro Pinto RC, etal. Minimally invasive esthetic therapy: A case report describing the advantages of a multidisciplinary approach. Quintessence Int 2013;44:385-91.

4. da Cunha LF,Pedroche LO, Gonzaga CC, Furuse AY. Esthetic, occlusal, and periodontal rehabilitation of anterior teeth with minimum thickness porcelain laminate veneers. JProsthetDent. 2014;112(6):1315-18.

5. Coachman C, Van DoorenE, Gürel G, Landsberg CJ, Calamita MA, Bichacho N.Smile design: From digital treatment planning to clinical reality. In: Cohen M (ed). Interdisciplinary Treatment Planning. Vol 2: Comprehensive Case Studies. Chicago: Quintessence, 2012:119-74.

6. Silness J. Fixed prosthodontics and periodontal health. Dent Clin North Am 1980;24:317-29

7. Clavijo VRC, Cavaretti MH, Beltrán MC, Ferreira LA, Andrade MF.Fragmentos cerâmicos. Clinica Int J Braz Dent. 2010; 6(3):290-99.

8. Gurel G, Sesma N, Calamita MA, Coachman C, Morimoto S. Influence of enamel preservation on failure rates of porcelain laminate veneers. Int J Periodontics Restorative Dent. 2013;33:31-9.

9. Levin RP. The future of porcelain laminate veneers. JEsthet Dent. 1989; 1(2):45-46.

10. Beier US et al. Clinical Performance of Porcelain Laminate Veneers for Up to 20 Years. Int JProsthodont. 2012;25:79-85.

11. Peumans M, De Munck J, Fieuws S, Lambrechts P, Vanherle G, Van Meerbeek B. A prospective ten-year clinical trial of porcelain veneers. J Adhes Dent. 2004;6(1):65-76.

12. Fradeani $M$, Redemagni $M$, Corrado M. Porcelain laminate veneers: 6- to 12-year clinical evaluation-A retrospective study. Int J Periodontics Restorative. 2005;25(1) 9-17.

13. Chiche G,Pinault A. Artistic and scientific principles applied to esthetic dentistry. In:Chiche G, Pianault A (eds). Esthetics of anterior fixed prosthodontics. Chicago: Quintessence Books, 1994:13-32.

14. Belser UC, Magne P,Magne M. Ceramic laminate veneers: Continuous evolution of indications. J Esthet Dent. 1997;9(4):197-207.

15. Radz GM. Minimum thickness anterior porcelain restorations. Dent Clin North Am. 2011;55(2):353-70. 
16. Kelly JR. Dental ceramics: current thinking and trends. Dent Clin North Am. 2004:48:513-30.

17. Duarte SJr, et al. Ceramic systems: An ultrastructural study. Quintessence Dent Technol. 2010;33:42-60.

18. Furuse AY,ScottiCK, Llerena-Icochea A, Bombonatti JFS, Haragushiku GA, Gonzaga CC. Influence of light activation of simplified adhesives on the shear bond strength of resin cements to a leucite-reinforced ceramic. Eur J Dent. 2018; 12(1):3-6.

19. Almeida JR, et al. Resin-based luting agents and color stability of bonded ceramic veneers. JProsthet Dent. 2015;114:272-77.
20. Runnacles P, Correr GM, Baratto Filho F, Gonzaga CC, Furuse AY. Degree of conversion of a resin cement light-cured through ceramic veneers of different thicknesses and types. Braz Dent J. 2014;25(1):38-42.

21. LuH, Powers JM. Color stability of resin cements after accelerated aging. Am J Dent 2004;17:354-58.

22. ScottiCK, Bastos NA, Velo MMAC, Zabeu GS, Bueno LS, Bombonatti JFS, Mondelli RFL Understanding the interaction of resin composite with light for predictable aesthetic results in anterior teeth: A case report. Braz Dent Sci 2018; 21(2):257-65.

\section{Prof. Dr. Marilia Mattar de Amoêdo Campos Velo}

\section{(Corresponding address)}

Department of Operative Dentistry, Endodontics and Dental Materials, Bauru School of Dentistry, University of São Paulo

Al. Dr. Otávio Pinheiro Brisolla 9-75 Vila Universitária -Bauru, SP, Brazil. CEP: 17012-901; Tel: +55-14-3235-8265

Email: mariliavelo@yahoo.com.br

Date submitted: 2019 Jun 30

Accept submission: 2019 0ct 01 